\title{
Wound grading and surgical site infection following caesarean section
}

\author{
Kavita Arya, Kishna Ram, Nupur Hooja*, Neha Singh, Aditi Jaiswal
}

Department of Obstetrics and Gynecology, SMS Medical College, Jaipur, Rajasthan, India

Received: 04 May 2021

Revised: 30 May 2021

Accepted: 31 May 2021

\author{
*Correspondence: \\ Dr. Nupur Hooja, \\ E-mail: nupurhooja@gmail.com
}

Copyright: ( ) the author(s), publisher and licensee Medip Academy. This is an open-access article distributed under the terms of the Creative Commons Attribution Non-Commercial License, which permits unrestricted non-commercial use, distribution, and reproduction in any medium, provided the original work is properly cited.

\begin{abstract}
Background: Surgical site infection (SSI) following caesarean section can adversely influence the postpartum period for the women. The objective of the study was to study the extent of infection and the microbiological flora in cases of surgical site infection following caesarean section.

Methods: Women undergoing caesarean section amongst women admitted in labour ward were followed till discharge for any surgical site infection Detailed assessment of the wound was done. Any discharge if present was taken for culture.

Results: $88.88 \%$ had normal wound healing, implying no infection. Of those with abnormal wound, $22 \%$ had serosanguinous or purulent discharge. Most had superficial incisional SSI. Enterococcus faecalis and Staphylococcus were the commonest organisms grown on culture.
\end{abstract}

Conclusions: All surgical site infections should be looked into as early as possible and managed appropriately.

Keywords: Deep spaces, Infection, Surgical site, Superficial, Wound

\section{INTRODUCTION}

Caesarean section (CS) is the most commonly performed major surgery worldwide. World Health Organization recommends that caesarean section rate should be in the range of $10-15 \%$ for attaining the best maternal and foetal outcome. ${ }^{1}$ In India, the rate has increasedto $32.6 \% .^{2}$ In the teaching hospitals in India it varies between $41-54 \%$, as these are also the tertiary care referral units. ${ }^{3}$

Surgical site infection (SSI) is defined as an infection that occurs after surgery in the part of the body where the surgery took place. It is classified as superficial, deep incisional and organ/space related. It is classified according to Center for Disease Control and Prevention (CDC) guidelines. ${ }^{4}$ SSI are associated with increased costs, higher rates of patient dissatisfaction, increased length of hospital stay and high mortality and morbidity rates. $^{5}$

Although caesarean sections are performed in a sterile environment, the risk of surgical site infection (SSI) always exist. Surgical site infection (SSI) following caesarean section can adversely influence the postpartum period for the women. These impact not only the physical health but also her emotional wellbeing. It influences a woman's ability to care for her infant, as well as her perception of her childbirth experience. Compared to women delivered vaginally, those delivered by caesarean have a 5 to 20 -fold increase in risk. ${ }^{6}$ Surgical site infection (SSI) complicates up to $8.9 \%$ caesarean sections. ${ }^{7}$ Rates of SSIs differ world over and are higher in less developed compared to developed countries where advanced hospital infection control protocols exist and correct implementation of evidence-based guidelines for SSI prevention are present. ${ }^{8}$

Although most caesarean section wound infection are superficial, however, a proportion of infections are more severe involving deeper tissue or reproductive organs necessitating extended hospital stays or readmission to hospital, adding further to morbidity and cost of treatment. Correct evaluation of the extent of the infection and the organisms involved would help in timely control. 
Since SSI following caesarean section is a very common entity and poses a considerable burden to our health care system, the objective of the study was to assess the rate and extent of surgical site infection following caesarean section during the hospital stay and the microbiological flora in these cases.

\section{METHODS}

This was a prospective descriptive type of observational study. The duration of study was from July 2020 to December 2020 for a period of six months. The study was done in the Department of Obstetrics and Gynaecology, SMS Medical College, Jaipur. Institutional review board and ethical committee approval was taken prior to the study.

Sample size of 442 caesarean deliveries was required for present study at $80 \%$ study power and alpha error of 0.05 assuming $6.8 \%$ incidence of surgical site infection following caesarean deliveries. ${ }^{9}$ It was further enhanced and rounded of to 450 caesarean deliveries as final sample size for the study.

\section{Inclusion criteria}

Women undergoing caesarean section, who understood and were willing to give consent to participate in the study were selected from amongst women admitted in labour ward.

\section{Exclusion criteria}

Women with local skin disease were excluded.

Informed consent of the women was taken prior to inclusion in the study.

After a detailed history and clinical examination, caesarean section was performed of all selected women by Misgav-Ladach method using Joel-Cohen incision for opening the abdomen using same suture material for all women. Antimicrobial prophylaxis was used as per hospital protocol.

Women were followed till discharge for any SSI detailed assessment of the wound was done by Southampton wound grading. ${ }^{10}$ Wound depth was graded according to CDC guidelines. ${ }^{4}$ Discharge if any was sent for culture and sensitivity test.

Data was compiled. All nominal/categorical variables were expressed as percentages. Appropriate tool was used for all statistical calculations and conclusions were drawn.

\section{RESULTS}

The mean age of the women included in the study was 25.29 years, $47.55 \%$ were educated more than secondary level. All women belonged to lower and middle socioeconomic class. In our study, most women were from the urban area $(59.55 \%)$ since the hospital is situated in the centre of the city and is easily approachable for the population. (93.11\%) had no history of smoking, tobacco chewing or alcohol intake and only $8.88 \%$ women were anaemic.

Four hundred women out of 450 had normal wound healing, grade 0 , implying no infection, $88.88 \%$. Majority of surgical site infections become apparent within 30 days of an operative procedure and most often between the $5^{\text {th }}$ and $10^{\text {th }}$ postoperative days. Diagnosis of surgical site infection requires evidence of clinical signs and symptoms of infection which may be further supported by microbiological evidence.

Table 1: Southampton wound scoring.

\begin{tabular}{|c|c|c|}
\hline Grade & LSCS & Percentage \\
\hline 0 Normal healing & & $400(88.88)$ \\
\hline 1-5 Abnormal wound & & $50(11.11)$ \\
\hline $\begin{array}{l}\text { I Normal healing with mild } \\
\text { bruising or erythema }\end{array}$ & 19 & \multirow{4}{*}{38} \\
\hline Ia Some bruising, & 9 & \\
\hline Ib Considerable bruising & 7 & \\
\hline Ic Mild erythema & 3 & \\
\hline $\begin{array}{l}\text { II Erythema plus other } \\
\text { signs of inflammation }\end{array}$ & 16 & \multirow{5}{*}{32} \\
\hline IIa At one point & 4 & \\
\hline IIb Around sutures & 4 & \\
\hline IIc Along wound & 6 & \\
\hline IId Around wound & 2 & \\
\hline $\begin{array}{l}\text { III Clear or haemoserous } \\
\text { discharge }\end{array}$ & 6 & \multirow{5}{*}{12} \\
\hline $\begin{array}{l}\text { IIIa At one point only }(\leq 2 \\
\mathrm{cm})\end{array}$ & 2 & \\
\hline IIIb Along wound $(>2 \mathrm{~cm})$ & 2 & \\
\hline IIIc Large volume & 1 & \\
\hline IIId Prolonged (> 3 days) & 1 & \\
\hline IV Pus & 5 & \multirow{3}{*}{10} \\
\hline IVa At one point only $(\leq 2 \mathrm{~cm})$ & 3 & \\
\hline IVb Along wound $(>2 \mathrm{~cm})$ & 2 & \\
\hline $\begin{array}{l}\text { V Deep or severe wound } \\
\text { infection with or without } \\
\text { tissue breakdown; } \\
\text { hematoma requiring } \\
\text { aspiration }\end{array}$ & 4 & 8 \\
\hline
\end{tabular}

On examining and grading the wound by Southampton wound grading, on postoperative day five, $70 \%$ had grade 1or 2 wound- those having mild erythema or with other signs of inflammation along and around the sutures and wound. $22 \%$ had serosanguinous or purulent discharge, grade 3 or 4 wound (Table 1).

According to CDC guidelines, superficial incisional SSI occurs within 30 days and involves only skin and subcutaneous tissue of the incision. ${ }^{4}$ Deep incisional SSI 
occurs within 30 or 90 days and involves deep soft tissues of the incision (e.g. fascial and muscle layers). Organ/space SSI occurs within 30 or 90 days and infection involves any part of the body, excluding the skin incision, fascia, or muscle layers, which was opened or manipulated during the operative procedure. In our study, $92 \%$ of the women with SSI developed only superficial surgical site infection. Only $8 \%$ of the women developed deep SSI (severe wound infection with tissue breakdown or hematoma requiring aspiration) (Table 2).

Table 2: CDC site of surgical infections.

\begin{tabular}{|ll|l|}
\hline Type of SSI & SSI cases $(\mathbf{n = 5 0})$ & Percentage \\
\hline Superficial & 46 & 92 \\
\hline Deep & 4 & 8 \\
\hline Organ space & 0 & 0 \\
\hline
\end{tabular}

Of the 50 women with abnormal wound healing, there was discharge from 15. In most of them, Enterococcus faecalis and Staphylococcus growth was found on culture. Mixed pathogens were also found in few (Table 3).

Table 3: Pathogens associated with post caesarean surgical site infection.

\begin{tabular}{|c|c|c|}
\hline Pathogens & $\begin{array}{l}\text { Number of } \\
\text { SSI cases }\end{array}$ & Percentage \\
\hline Enterococcus faecalis & 4 & 8 \\
\hline $\begin{array}{l}\text { Staphylococcus } \\
\text { saprophyticus }\end{array}$ & 3 & 6 \\
\hline $\begin{array}{l}\text { Staphylococcus aureus } \\
\text { (MRSA) }\end{array}$ & 2 & 4 \\
\hline $\begin{array}{l}\text { Acinetobactor }+ \\
\text { Staphylococcus l } \\
\text { epidermidis }\end{array}$ & 1 & 2 \\
\hline $\begin{array}{l}\text { Enterococcus faecalis } \\
+ \text { Candida tropicalis }\end{array}$ & 1 & 2 \\
\hline
\end{tabular}

\section{DISCUSSION}

The American College of Obstetricians and Gynaecologists recommends antibiotic prophylaxis during caesarean section by receiving antibiotics within 1 hour before the start of surgery. In the case of emergency caesarean section, prophylaxis should be started as soon as possible. ${ }^{11}$ The recommended prophylactic antibiotic for caesarean section is cefazolin 1-2 gm i.v. For patients allergic to penicillins and cephalosporins, clindamycin with gentamicin is a reasonable alternative. ${ }^{6}$

Since all the women in our study were given postoperative antibiotic, this is often the reason that no organisms are found on culture even in the presence of surgical site infection.

Vallejo et al found that during caesarean section the surgical site is exposed to vaginal polymicrobial aerobic and anaerobic flora accounting for the higher incidence of infection compared to other types of surgical procedure that only break the skin surface. ${ }^{12}$ Hence, these operations are classified as clean contaminated cases.

Skin is normally colonised by a range of microorganisms that could cause infection. In clean-contaminated procedures like caesarean section, the polymicrobial aerobic-anaerobic flora closely resembling the normal endogenous microflora of the operated organ constitutes the most frequently isolated pathogens. Amongst the aerobic bacterial agents causing surgical site infection in caesarean section patients, enteric gram negative bacilli is the most common followed by enterococci and group B streptococci. Clostridia and Bacteroides are commonly isolated anaerobic organisms. These endogenous vaginal flora are usually introduced following repeated vaginal examinations or instrumentation. Considering that the postoperative caesarean section infections could be polymicrobial, the samples should be appropriately processed for aerobic, anaerobic, fastidious bacteria, slow growing organisms and fungi.

Sullivan et al found a lower incidence of endometritis and wound infection with preoperative antibiotic administration compared to the previous practice of later administration after the umbilical cord had been clamped to prevent antibiotics from crossing over to the newborn. ${ }^{13}$

Similar to our study, Wloch et al found that the majority of infections reported from caesarean sections were superficial incisional infections. ${ }^{14}$ There were too few deep incisional or organ/space (uterine and reproductive tract infections).

Zejnullahu et al also found that the majority of the infections in their study sample were superficial infections $(93.75 \%)$ whereas $6.25 \%$ were deep primary incisional surgical site infections. ${ }^{15}$ Organ/space surgical site infection or endometritis based on patient- reported criteria (uterine tenderness, abdominal pain and purulent discharge from the uterus) as defined, were not identified in their study too.

There are some limitations of the study. The study was performed in a single centre which is a tertiary referral government hospital, hence, selection bias may have been there. All patients were given prophylactic antibiotics, so the incidence of SSI may be less than in other places.

\section{CONCLUSION}

Although superficial incisional infections are relatively minor, they are still likely to result in pain and discomfort, require antimicrobial therapy and might progress to affect deeper tissues. Avoiding more severe infections by monitoring superficial ones is essential, to detect early any potential problems. Furthermore, all infections would result in costs to the health service through extended hospital stay and visits to the doctors. 
Funding: No funding sources

Conflict of interest: None declared

Ethical approval: The study was approved by the Institutional Ethics Committee

\section{REFERENCES}

1. Sreevidya S, Sathiyasekaran BW. High caesarean rates in Madras (India): a population-based cross sectional study. BJOG Int J Obstet Gynaecol. 2003;110(2):106-11.

2. Vitale SG, Marilli I, Cignini P, Padula F, D’Emidio L, Mangiafico L, et al. Comparison between modified Misgav-Ladach and Pfannenstiel- Kerr techniques for Caesarean section: review of literature. J Prenat Med. 2014 Apr;8(3-4):36.

3. Bhargava S, Hooja N, Kala M, Mital P, Tulani K, Arora S, et al. Caesarean delivery in the second stage of labour at a tertiary care hospital. J Obstet Gynecol India. 2019;69(6):558-60.

4. Horan TC, Andrus M, Dudeck MA. CDC/NHSN surveillance definition of health care associated infection and criteria for specific type of infection in acute care setting. AMJ Infect Control. 2008;36:30932.

5. Berríos-Torres SI, Umscheid CA, Bratzler DW, Leas B, Stone EC, Kelz RR, et al. Centers for disease control and prevention guideline for the prevention of surgical site infection, 2017. JAMA Surg. 2017;152(8):784-91.

6. Tita AT, Rouse DJ, Blackwell S, Saade GR, Spong $\mathrm{CY}$, Andrews WW. Evolving concepts in antibiotic prophylaxis for cesarean delivery: a systematic review. Obstet Gynecol. 2009;113(3):675.

7. Opoien HK, Valbo A, Grinde-Anderson A, Walberg M. Post caesarean surgical site infections according to CDC standards: rates and risk factors. A prospective cohort study. Acta Obstet Gynecol Scand. 2007;86:1097-102.
8. Raka L. Prevention and control of hospital-related infections in low and middle income countries. Open Infect Dis J. 2010;4:125-31.

9. Gelaw KA, Aweke AM, Astawesegn FH, Demissie BW, Zeleke LB. Surgical site infection and its associated factors following cesarean section: a cross sectional study from a public hospital in Ethiopia. Patient Safety Surg. 2017;11(1):1-7.

10. Williams NS, O'Connell PR, McCaskie A, eds. Bailey and Love's short practice of surgery. 27th edn. CRC press; 2018.

11. Committee Opinion no. 465. Antimicrobial prophylaxis for caesarean delivery: Timing of administration. Obstet Gynecol. 2010;465:791-2.

12. Vallejo MC, Attaallah AF, Shapiro RE, Elzamzamy OM, Mueller MG, Eller WS. Independent risk factors for surgical site infection after cesarean delivery in a rural tertiary care medical center. J Anesth. 2017;31(1):120-6.

13. Sullivan SA, Smith T, Chang E, Hulsey T, Vandorsten JP, Soper D. Administration of cefazolin prior to skin incision is superior to cefazolin at cord clamping in preventing postcesarean infectious morbidity: a randomized, controlled trial. Am J Obstet Gynecol. 2007;196(5):455-e1.

14. Wolch C, Wilson J, Lamagni $\mathrm{T}$, Harrington $\mathrm{P}$, Charlett A, Sheridan E. Risk factors for surgical site infection following caesarean section in England: results from a multicentre cohort study. BJOG. 2012;119:1324-33.

15. Zejnullahu VA, Isjanovska R, Sejfija Z, Zejnullahu VA. Surgical site infections after cesarean sections at the University Clinical Center of Kosovo: rates, microbiological profile and risk factors. BMC Infect Dis. 2019;19(1):1-9.

Cite this article as: Arya K, Ram K, Hooja N, Singh $\mathrm{N}$, Jaiswal A. Wound grading and surgical site infection following caesarean section. Int J Reprod Contracept Obstet Gynecol 2021;10:2667-70. 